\title{
Data on the morphology of Viguiera dicrurusi Gupta, 1960 (Nematoda: Habronematidae) with notes on related forms
}

\author{
Anadi P. Nandi \\ Parasitology Laboratory, Department of Zoology, The University of Burdwan, Burdwan 713 104, India
}

Key words: Nematoda, morphology, SEM, Viguiera dicrurusi, Viguiera viduae

\begin{abstract}
Morphology of the nematode Viguiera dicrurusi Gupta, 1960 harboured by Dicrurus macrocercus albirictus (Hodgson) (Passseriformes: Dicruridae) from Baruipara in 24-Pargonas (South) district, West Bengal, India was studied by light and scanning electron microscopy (SEM). This represents the first study of $V$. dicrurusi using SEM. Scanning electron micrographs provided detailed information about the nature of pseudolabial plates, number and shape of teeth, dentate nature of striae, and the relative position of vulva, anus and phasmid opening in female. A detailed morphometrical comparison of this species with Viguiera viduae Chabaud, 1960 described from Dicrurus forficatus from Madagascar indicates that $V$. viduae is a junior synonym of $V$. dicrurusi. Two other species, Viguiera bhujangai Jehan, 1972 and Viguiera adsimilisai Sood et Kalia, 1978 are considered species inquirendae.
\end{abstract}

The genus Viguiera Seurat, 1913 now includes 20 species; of these 9 have been described from the Indian Subcontinent. The cephalic structures are important taxonomic features of this genus, and have been inadequately described in some of the Indian species, which include Viguiera dicrurusi Gupta, 1960, Viguiera bhujangai Jehan, 1972 and Viguiera adsimilisai Sood et Kalia, 1978. These three species and Viguiera majumdari De, 1979 have been described from similar or related hosts of the same zoogeographical region and are very close in their various body measurements. Viguiera indica Jehan, 1972 is based on a single male specimen. The cephalic structure of $V$. majumdari is quite different from $V$. dicrurusi, and in $V$. indica the left spicule is much longer than in other Indian congeners; therefore, they are considered distinct species. Unfortunately, types of $V$. bhujangai and $V$. adsimilisai are not available for restudy. The place of deposition of the type specimens of $V$. bhujangai was not mentioned in the literature and no reply in this regard was received from the institution where the author worked. The types of $V$. adsimilisai are lost. Viguiera bhujangai and $V$. adsimilisai are thus considered species inquirendae.

New data are added on the morphology of $V$. dicrurusi below, based on studies with the light microscope (LM) and scanning electron microscope (SEM).

\section{MATERIALS AND METHODS}

For the present study eight black drongoes [Dicrurus macrocercus albirictus (Hodgson)], collected from Baruipara, 24Pargonas (South) district, West Bengal, India were examined for nematode infection. Five out of the eight hosts were found to be infected. Sixteen male and nineteen female nematodes were recovered from under the horny layer of the gizzard of the infected hosts. The worms were washed thoroughly by shaking in $0.85 \%$ saline. Eight males and eleven females were fixed in hot $4 \%$ formaldehyde and were cleared in $5 \%$ glycerine for LM study.

For SEM study, eight males and eight females were fixed in $2.5 \%$ glutaraldehyde in $0.2 \mathrm{M}$ sodium cacodylate buffer at $\mathrm{pH} 7.0$ for 4 hours. After primary fixation, the anterior and poste-rior ends of the worms were cut off by using a sharp razor blade to promote better fixation and minimize shrinkage. The cut ends were postfixed for 12 hours in $2 \%$ osmium tetroxide in the same buffer, dehydrated in ascending series of ethanol, transferred to $100 \%$ isoamyl acetate through mixtures of ethanol and isoamyl acetate and dried in a Hitachi HPC-2 (Japan) critical point drying apparatus. The dried specimens were mounted on aluminium stubs and coated with gold by an IB2 ion coater. Observations were carried out with a Hitachi S-530 (Japan) scanning electron microscope with a resolution of $50 \AA$ and operating at an accelerating voltage of $15 \mathrm{kV}$.

\section{RESULTS}

Morphologically (Figs. 1-12) the worms in this study agree mainly with the description of Viguiera viduae Chabaud, 1960. Metrically they come close to this species but are closer to Viguiera dicrurusi Gupta, 1960 (Table 1). In the present nematodes the posterior margin of the inter-striae cuticle, except that of the most anterior and posterior region, is finely dentate (Figs. 7-10). The mouth opening is elongate oval and is guarded by two lateral pseudolabia, each of which bears four small chisel-shaped teeth at its anterior margin (Figs. 4-6). The lateral cuticular plates of the pseudolabia are concave at their centre and each bears two pairs of anterior and two pairs of posterior projections (Figs. 5, 6). The outer anterior projections of the pseudolabial plates partly cover the mouth opening, leaving a narrow slit at its dorsal and ventral side (Figs. 4-6). Two pairs of 


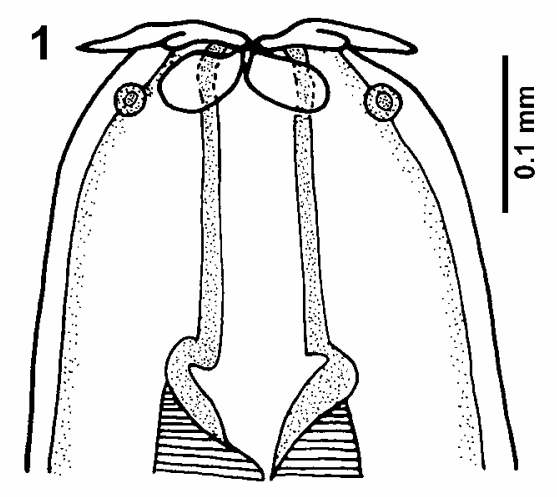

2

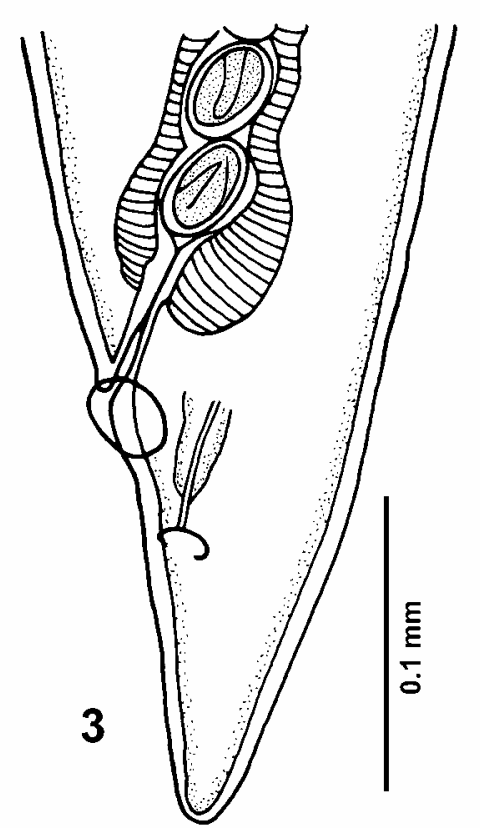

2

(1)
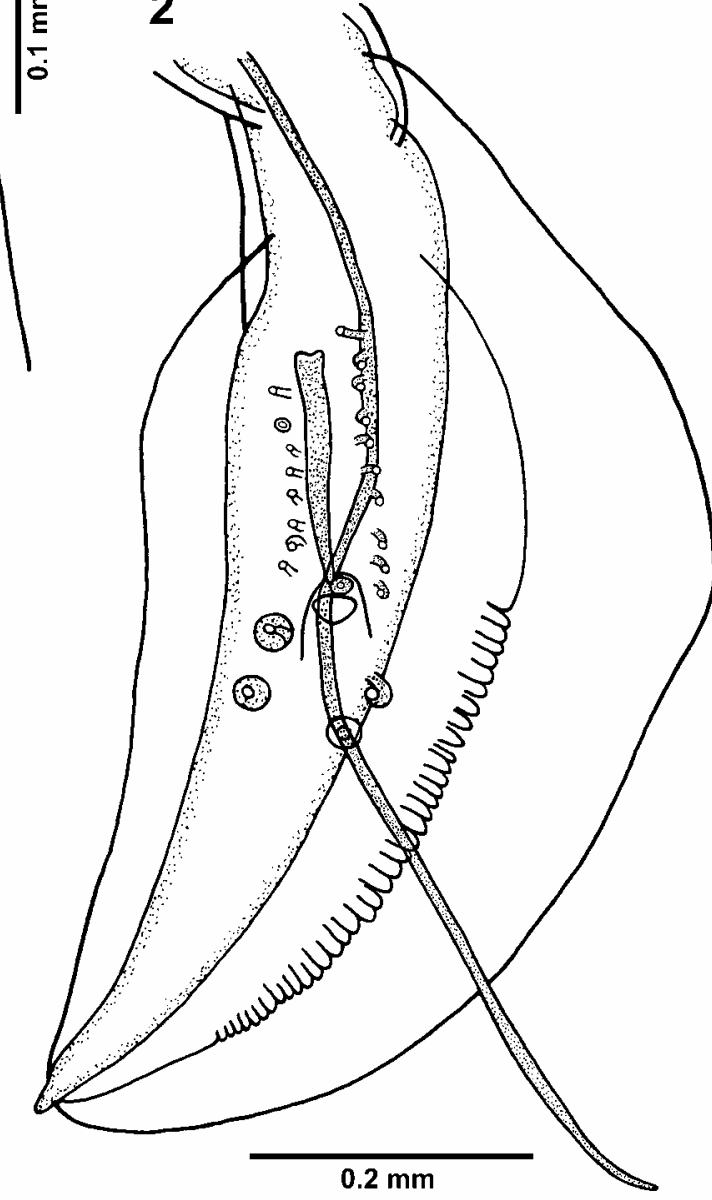

Figs. 1-3. Viguiera dicrurusi Gupta, 1960. Fig. 1. Anterior end of female, ventral view. Fig. 2. Posterior end of male, ventral view. Fig. 3. Posterior end of female, ventro-lateral view.

wing-like cuticular blades extend posteriorly from the dorsal and ventral margins of the mouth opening (Figs. $1,4,6)$. Four large submedian cephalic papillae and two lateral amphids lie immediately behind the lateral plates (Figs. 1, 4-6). The excretory pore is circular and bordered by a cuticular rim (Fig. 7). The cervical papillae are spine-like and each projects from small cuticular elevation (Fig. 8).

The posterior end of the male is ventrally spirally coiled and an SEM study of the cloacal region could not be made. The LM study of the male tail (Fig. 2) revealed that it is provided with asymmetrical caudal alae; the left ala is broader than the right and is longitudinally marked like ctenidial filaments at its inner half. The number of preanal papillae is $8-9$ on the right margin and 9-10 on the left. In addition, there is a single median precloacal papilla and two pairs of postanal papillae, larger than preanals and positioned in the anterior half of the tail.
The female tail (Fig. 11) bears cuticular bosses at its distal tip. The vulva with distinct cuticular rim is located very near and anterior to the anus but lies on the right margin of the ventral surface, not on the midventral line (Figs. 3, 11). The phasmids are subterminal (Fig. 11). The scanning electron micrograph of the egg (Fig. 12) shows no special features. The egg shell appears to be wrinkled.

H o s t: Dicrurus macrocercus albirictus (Hodgson) (Passseriformes: Dicruridae).

$\mathrm{L}$ o c a t i o $\mathrm{n}$ : Under the horny layer of gizzard.

L o c a 1 i t y : Baruipara, 24-Pargonas (South), West Bengal, India.

S p e c i m e n s : 16 males and 19 females. Voucher specimens have been deposited in the Helminthological collection, Parasitology Laboratory, Burdwan University, Burdwan, West Bengal, India, Coll. No. BUPL-148. 

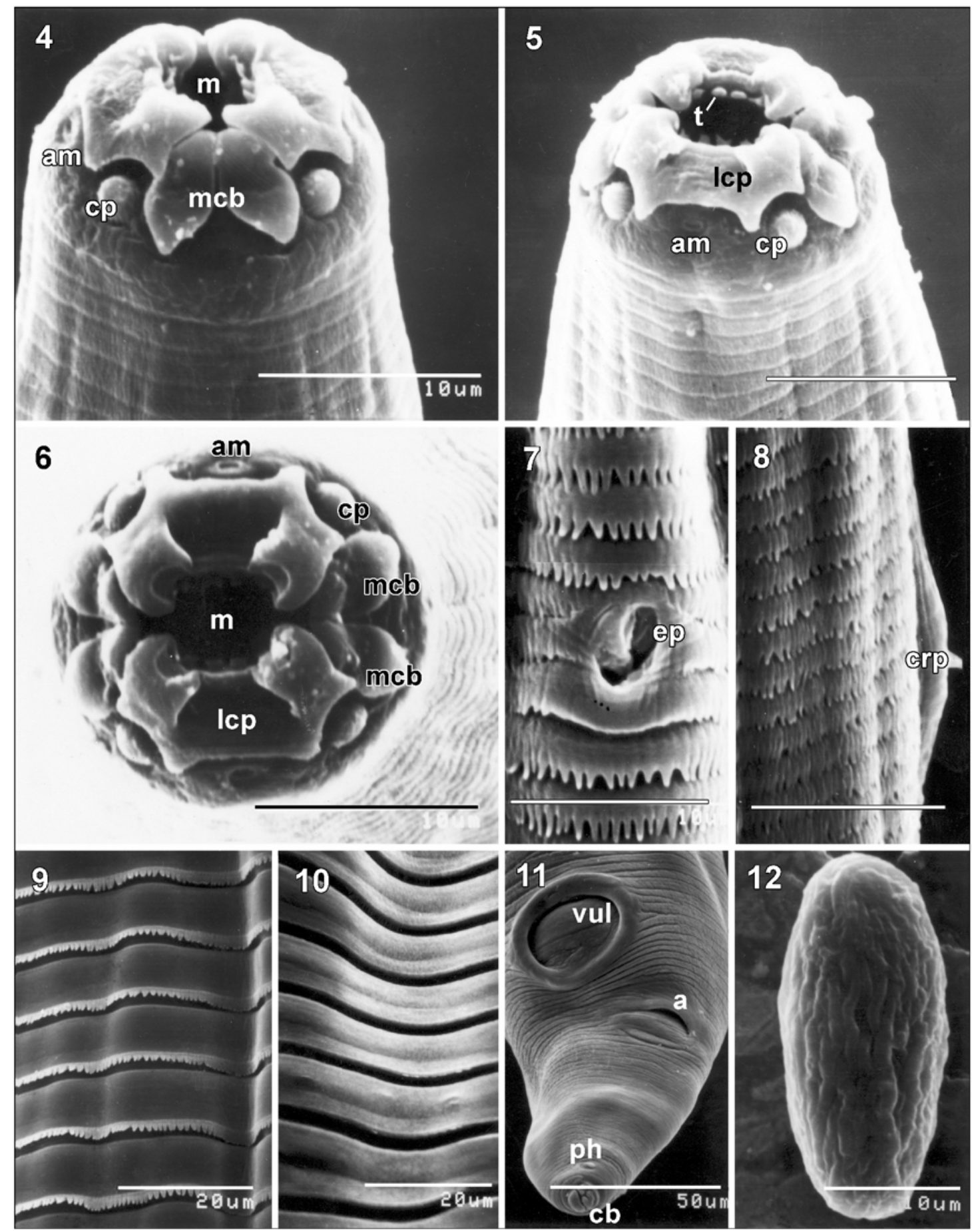

Figs. 4-12. Viguiera dicrurusi, scanning electron micrographs. Fig. 4. Anterior end of female, ventral view. Fig. 5. Anterior end of female, lateral view. Fig. 6. Cephalic extremity of female, en face view. Fig. 7. Cervical region of male showing excretory pore, ventral view. Fig. 8. Cervical region of male showing one of the cervical papillae, dorsal view. Fig. 9. Middle region of female showing dentate striae. Fig. 10. Posterior region of female showing edentate striae. Fig. 11. Posterior end of female showing relative position of anus, vulva and phasmid, ventro-lateral view. Fig. 12. Egg. Abbreviations: a - anus; am - opening of amphid; cb - cuticular bosses; cp - cephalic papilla; crp - cervical papilla; ep - excretory pore; lcp - lateral cuticular plate; $\mathrm{m}$ mouth; mcb - median cuticular blade; $\mathrm{ph}$ - opening of phasmid; $\mathrm{t}$ - tooth; vul - vulva. Scale bars: Figs. 5-8 =10 $\mu \mathrm{m}$. 


\section{DISCUSSION}

The genus Viguiera was created by Seurat (1913) with Viguiera euryoptera (Rudolphi, 1918) as the type species. Chabaud (1960, 1975) considered Serticeps Railliet, 1916 and Spirocaudata Sharma, 1971 as synonyms of Viguiera. This genus now includes 20 species of which 9 have been reported from the Indian Subcontinent. Gupta (1960) considered V. euryoptera reported by Singh (1949) from India was a wrong identification and may belong to Viguiera dicrurusi Gupta, 1960.

Gupta (1960) described V. dicrurusi from Dicrurus macrocercus albirictus in East Pakistan (Bangladesh) and Chabaud (1960) described Viguiera viduae from Dicrurus forficatus in Madagascar, Africa. The nematodes obtained for this study are from same host and same zoogeographical region as that of $V$. dicrurusi and are morphologically almost identical to $V$. viduae. Metrically they are also close to it (Table 1) except the left spicule, which is slightly longer in the present form. Chabaud's description, though based on LM study, is so comprehensive that SEM study of the present material adds little to the original data. Moreover, restudy of the type material of $V$. viduae (loan no. 2003/09 of Collections d'Helminthes, Muséum National d'Histoire Naturelle, Paris) by light microscope revealed its close similarity with the specimens obtained for this study. Scanning electron micrographs revealed that the mouth opening is elongate oval and each pseudolabium bears four small chisel-shaped teeth. Each lateral pseudolabial plate bears two pairs of anterior projections near oral margin in addition to two pairs of posterior projections. The scanning electron micrographs show the presence of four cephalic papillae and two lateral amphids.

SEM observation of the cloacal region of the male could not be made but the LM study revealed that the present form differs from Chabaud's specimens only by one or two additional preanal papillae on either margin. The scanning electron micrograph of the female tail shows cuticular bosses at its distal tip, subterminal phasmids, and the subventral position of the vulva, which have not been previously reported.

A comparison of available data of $V$. dicrurusi with that of the nematodes in this study reveals that they are very close to $V$. dicrurusi in metrical range (Table 1) and general morphology. The present worms have been recovered from the same host and the same zoogeographical region as $V$. dicrurusi. The type specimens of $V$. dicrurusi could not be re-examined since the place of deposition had not been mentioned in the literature. The author tried to borrow the types from Helminthological Collection of McGill University. Enquiries as to the location of the type specimens to the Director, Institute of Parasitology, McGill University were unsuccessful. The main difference between the present worms and $V$. dicrurusi lies in the number of postanal papillae (two pairs in present material, four pairs in $V$. dicrurusi). The postanal papillae of the genus Viguiera can only be studied properly in ventral view. It appears from Gupta's illustrations of $V$. dicrurusi (his figs. 6-8) that the author studied his material without properly uncoiling the caudal region and may have mistaken the papillae of both margins as those of one. The present study reveals that the number of preanal papillae may range from eight to nine pairs with one extra papilla on the left margin. The notch formed between the anterior projections of the pseudolabial plates on each side was mistakenly described as an 'aperture' or 'papilla' in $V$. dicrurusi. The teeth and the serrated nature of the striae were not described by Gupta (1960).

Chabaud (1960) compared his material of $V$. viduae with $V$. euryoptera. In the footnote (p. 113) he also distinguished $V$. dicrurusi from $V$. viduae by the longer left spicule and smaller eggs. $V$. dicrurusi also seems to differ from $V$. viduae in many morphological features since $V$. dicrurusi has been inadequately described. Chabaud thus considered it as a distinct species.

It follows from the above discussion that there are no substantial morphological differences amongst $V$. dicrurusi and $V$. viduae. The description of $V$. dicrurusi was published in February, 1960. The description of $V$. viduae was also published in the same year but the date of publication was not mentioned in the journal (Mr. J. Cassone, Mus. Natl. Hist. Nat., Paris, pers. comm.). However, Chabaud (1960) in his footnote (p. 113) reported that "Viguiera dicrurusi Gupta, 1960, parasite of Dicrurus in Pakistan was published in Canadian J. Zool. during the impress of this reprint". It is, therefore, apparent that $V$. dicrurusi was published earlier than $V$. viduae and $V$. dicrurusi is the valid name for this species in view of priority. Viguiera viduae Chabaud, 1960 is consequently a junior synonym of this species. The specimens described in this study are thus assigned to $V$. dicrurusi.

Three other species of Viguiera have been described from India from similar or related host species to that of $V$. dicrurusi, namely, Viguiera bhujangai Jehan, 1972 from Dicrurus adsimilis macrocercus; Viguiera adsimilisai Sood et Kalia, 1978 from Dicrurus adsimilis; and Viguiera majumdari De, 1979 from Dicrurus macrocercus macrocercus. All three forms are close to $V$. dicrurusi in metrical data (Table 1) and general morphology. The cephalic structures are major distinguishing features for species of Viguiera and the cephalic region is poorly illustrated and inadequately described for $V$. bhujangai and $V$. adsimilisai. The cephalic structure of $V$. majumdari clearly indicates its distinction from $V$. dicrurusi. Apart from cephalic structures, $V$. bhujangai differs from $V$. dicrurusi and $V$. majumdari only in having 10 pairs of preanal papillae, which seems to be a variable character, since De (1979) recorded a range in the number of preanal papillae between five and nine pairs in $V$. majumdari. Sood and Kalia (1978) distinguished $V$. adsimilisai from $V$. bhujangai mainly on the basis of greater spicule ratio $(1: 4$ vs. $1: 2$ to $1: 2.5)$ but the 
Table 1. Comparison of measurements of the related forms of Viguiera (all measurements in mm)

\begin{tabular}{|c|c|c|c|c|c|c|}
\hline Species reference & $\begin{array}{l}\text { V. dicrurusi } \\
\text { Gupta } 1960\end{array}$ & $\begin{array}{c}\text { V. viduae } \\
\text { Chabaud } 1960\end{array}$ & $\begin{array}{l}\text { V. bhujangai } \\
\text { Jehan } 1972\end{array}$ & $\begin{array}{l}\text { V. adsimilisai } \\
\text { Sood and Kalia } 1978\end{array}$ & $\begin{array}{l}\text { V. majumdari } \\
\text { De } 1979\end{array}$ & $\begin{array}{c}V . \text { dicrurusi } \\
\text { Own specimens }\end{array}$ \\
\hline $\begin{array}{l}\text { M A L E } \\
\text { Body length } \\
\text { Width } \\
\text { Length of vestibule } \\
\text { Length of muscular oesophagus } \\
\text { Length of glandular oesophagus } \\
\text { Nerve ring from anterior end } \\
\text { Cervical papillae from anterior end } \\
\text { Excretory pore from anterior end } \\
\text { Length of right spicule } \\
\text { Length of left spicule } \\
\text { Spicule ratio } \\
\text { Length of caudal alae } \\
\text { Width of caudal alae } \\
\text { left } \\
\text { right } \\
\text { Length of tail } \\
\text { Number of preanal papillae } \\
\text { Number of postanal papillae }\end{array}$ & $\begin{array}{c}6.02-6.98 \\
0.17-0.21 \\
0.03-0.04 \\
0.36-0.40 \\
1.82-2.42 \\
0.26-0.28 \\
0.13-0.14 \\
0.25-0.27 \\
0.16-0.19 \\
1.10-1.24 \\
1: 6.52-6.87 \\
- \\
- \\
- \\
0.30-0.36 \\
8 \text { pairs } \\
4 \text { pairs? }\end{array}$ & $\begin{array}{c}5.30 \\
0.15 \\
0.022 \\
0.35 \\
2.40 \\
0.245 \\
0.13 \\
0.245 \\
0.175 \\
0.880 \\
1: 5.02 \\
0.70 \\
\\
0.14 \\
0.07 \\
0.37 \\
7 \text { pairs }+1 \mathrm{~lm}+1 \mathrm{pc}^{1} \\
2 \text { pairs }\end{array}$ & $\begin{array}{c}6.50-6.66 \\
0.13-0.20 \\
0.022-0.030 \\
0.37-0.39 \\
2.00-2.31 \\
0.27-0.28 \\
0.12-0.15 \\
0.17-0.18 \\
0.164-0.185 \\
0.87-1.21 \\
1: 5.3-6.5 \\
0.60-0.65 \\
- \\
- \\
0.40-0.46 \\
10 \text { pairs } \\
2 \text { pairs }\end{array}$ & $\begin{array}{c}4.02-6.23 \\
0.16-0.20 \\
0.022-0.030 \\
0.66-0.98 \\
1.64-2.70 \\
0.20-0.30 \\
\text { absent? } \\
0.23-0.34 \\
0.14-0.30 \\
0.55-1.19 \\
1: 4 \\
- \\
- \\
- \\
- \\
10 \text { pairs } \\
2 \text { pairs }\end{array}$ & $\begin{array}{c}5.12-6.63 \\
0.20-0.22 \\
0.02-0.03 \\
0.248-0.267 \\
2.632-2.953 \\
0.18-0.22 \\
0.091-0.121 \\
0.20-0.27 \\
0.16-0.20 \\
1.17-1.18 \\
1: 5.9-7.3 \\
0.63-0.88 \\
- \\
- \\
0.41-0.54 \\
5-9 \text { pairs } \\
2 \text { pairs }\end{array}$ & $\begin{array}{c}5.76-7.19 \\
0.19-0.23 \\
0.02-0.03 \\
0.29-0.39 \\
2.40-2.85 \\
0.22-0.25 \\
0.13-0.14 \\
0.23-0.26 \\
0.17-0.18 \\
1.03-1.26 \\
1: 6.06-7.00 \\
0.60-0.70 \\
0.15 \\
0.09 \\
0.45 \\
8-9 \text { pairs }+11 \mathrm{~lm}+1 \mathrm{pc}^{1} \\
2 \text { pairs }\end{array}$ \\
\hline $\begin{array}{l}\text { F E M A L E } \\
\text { Body length } \\
\text { Width } \\
\text { Length of vestibule } \\
\text { Length of muscular oesophagus } \\
\text { Length of glandular oesophagus } \\
\text { Nerve ring from anterior end } \\
\text { Cervical papillae from anterior end } \\
\text { Excretory pore from anterior end } \\
\text { Vulva from anterior end } \\
\text { Length of tail } \\
\text { Eggs }\end{array}$ & $\begin{array}{c}8.00-11.22 \\
0.24-0.28 \\
0.03-0.04 \\
0.34-0.50 \\
2.20-2.92 \\
0.30 \\
0.15-0.16 \\
0.26-0.28 \\
0.16-0.17 \\
0.12-0.14 \\
0.24-0.34 \times \\
0.20-0.30^{3} \\
\end{array}$ & $\begin{array}{c}7.00 \\
0.17 \\
0.022 \\
0.30 \\
2.30 \\
0.24 \\
0.135 \\
0.24 \\
0.14 \\
0.10 \\
0.037 \times \\
0.028 \\
\end{array}$ & $\begin{array}{c}9.40 \\
0.20 \\
0.03 \\
0.37 \\
2.70 \\
0.25 \\
0.15 \\
0.28 \\
0.16 \\
- \\
0.032-0.040 \times \\
0.020-0.023 \\
\end{array}$ & $\begin{array}{c}6.07-10.08 \\
0.23-0.28 \\
0.024-0.040 \\
0.40-0.98 \\
1.63-2.29 \\
0.14-0.26 \\
\text { absent? } \\
0.182-0.293 \\
- \\
- \\
0.022-0.044 \times \\
0.016-0.020 \\
\end{array}$ & $\begin{array}{c}7.98-11.02 \\
0.25-0.30 \\
0.019-0.021 \\
0.251-0.340 \\
2.569-3.020 \\
0.18-0.22 \\
0.108-0.126 \\
0.21-0.25 \\
0.107-0.148^{2} \\
0.10-0.11 \\
0.038-0.040 \times \\
0.019-0.021 \\
\end{array}$ & $\begin{array}{c}10.04-10.76 \\
0.27-0.28 \\
0.03-0.04 \\
0.37-0.44 \\
3.10-3.20 \\
0.26 \\
0.13-0.16 \\
0.25-0.26 \\
0.14-0.17 \\
0.11-0.13 \\
0.031-0.041 \times \\
0.021-0.024 \\
\end{array}$ \\
\hline Hos T & $\begin{array}{l}\text { Dicrurus macrocercus } \\
\text { albirictus }\end{array}$ & Dicrurus forficatus & \begin{tabular}{|l|} 
Dicrurus adsimilis \\
macrocercus
\end{tabular} & Dicrurus adsimilis & $\begin{array}{l}\text { Dicrurus macrocercus } \\
\text { macrocercus }\end{array}$ & $\begin{array}{l}\text { Dicrurus macrocercus } \\
\text { albirictus }\end{array}$ \\
\hline
\end{tabular}

${ }^{1} \mathrm{~lm}$ - left margin, pc - precloacal; ${ }^{2}$ by conversion of the ratio of vulva to body length; ${ }^{3}$ probably an error for $0.024-0.034 \times 0.020-0.030$ 
metrical data of the spicules as also the text figure (pl. 1, fig. 3) of $V$. bhujangai clearly show it to be $1: 5.3$ to 1 : 6.5 , which is close to $V$. adsimilisai. In addition, both these species have been recovered from the same host species and zoogeographical region. It can, therefore, be presumed that $V$. bhujangai and $V$. adsimilisai belong to a single species and study of type specimens might reveal their conspecificity with either $V$. dicrurusi or $V$. majumdari. The type specimens of $V$. bhujangai are not available since place of deposition has not been mentioned in the literature and no reply on enquiries as to the location of the types was received from the institution (Department of Zoology, Lucknow University, Lucknow) where the work was done. The types of $V$. adsimilisai are lost (Prof. M.L. Sood, Dept. of Zool., Punjab Agric. Univ., Ludhiana, India; pers. comm.). Viguiera bhujangai and $V$. adsimilisai are thus regarded as species inquirendae.

Acknowledgements. Thankful acknowledgement is due to the University of Burdwan for financial assistance. The author is thankful to Prof. A.G. Chabaud, Laboratoire de Zoologie, and Mr. Jimmy Cassone, Chargés des Collections d'Helminthes, both of Muséum National d'Histoire Naturelle, Paris, for providing reprints and lending the type specimens. The author thankfully acknowledges Mr. Subrata Biswas for his assistance in collection and preparation of the material and Dr. Srikanta Bhattacharya of USIC \& CIF, Burdwan University for an excellent technical assistance in SEM study.

\section{REFERENCES}

CHABAUD A.G. 1960: Quatre Spirurides parasites d'oiseaux malgaches (1). Mem. Inst. Sci. Madagascar, Sér. A, 14 $105-124$.

CHABAUD A.G. 1975: Keys to the genera of the order Spirurida. Part 2. Spiruroidea, Habronematoidea and Acuarioidea. CIH keys to the nematode parasites of vertebrates. No. 3. Commonwealth Agricultural Bureaux, England, pp. 29-58.

DE N.C. 1979: Viguiera majumdari sp. n. (Nematoda: Habronematidae) from the bird Dicrurus m. macrocercus (Vieill.) from West Bengal, India. Folia Parasitol. 26: 7376.

GUPTA S.P. 1960: Nematode parasites of vertebrates of East Pakistan. V. Spirurid nematodes. Can. J. Zool. 38: 575584.

Received 6 January 2003
JEHAN M. 1972: On two new species of the genus Viguiera Seurat, 1913 from the gizzard of birds. Proc. Natl. Acad. Sci. India, Sect. B, 41: 287-292 (1971).

SEURAT L.G. 1913: Sur le Spiroptère des pies-grièches. Bull. Soc. Hist. Nat. Afr. Nord 5: 223-225.

SINGH S.N. 1949: Studies on the helminth parasites of birds in Hyderabad State. Nematoda. III. J. Helminthol. 23: 2528.

SOOD M.L., KALIA R. 1978: Viguiera adsimilisai n. sp. (Nematoda: Spiruridae) from Dicrurus adsimilis from India. Riv. Parassitol. 39: 23-25.

Accepted 19 November 2004 